\title{
WITCHCRAFT ACCUSATIONS AND THEIR SOCIAL SETTING: CASES IN THE LIMPOPO PROVINCE ${ }^{1}$
}

\author{
S.T. Kgatla ${ }^{2}$ \\ University of Pretoria \\ thias.kgatla@up.ac.za
}

\section{ABSTRACT}

This article is the result of research findings undertaken in Limpopo Province on the subject of witchcraft beliefs. It is a narration of two villages whose residents were accused of witchcraft and had to be moved to other villages for their safety. Socio-economic conditions responsible for the communities to accuse their members of witchcraft are analysed. In the last part of the paper I draw on some classical theoretical approaches such as projection, scapegoating and materialism theories. In conclusion three statements are considered: 1) witchcraft is something real in human experience; 2) witchcraft is an imaginary crime; 3 ) an explanation of witchcraft accusations seen through the lens of social theories on society.

Keywords: witchcraft, social theories, scapegoating, co-wives, social cohesion

\section{UNISA}




\section{INTRODUCTION}

In order to provide a satisfactory explanation for the witchcraft accusations in the Limpopo Province of South Africa, one should consider not only the religious changes and conflicts but also the broader social environment in which these accusations are made. Levack (1987: 125) maintains that in studying any crime, we can profit from acquiring knowledge of the social setting of the crime and the relationship between the criminal and his/her victim. Variables such as the economic condition of the community, sex and age of the victims, agricultural conditions, infrastructure, social cohesion and poverty levels of the community are considered (Baholo 1994: 4). In that way we can fully understand what motivated the criminal and his/her persecutors. In this article we will investigate the social relationships of victims of witchcraft-hunting. Such an inquiry can help us explain why the alleged victims of the crime, or their kin, are singled out for persecution.

In my opinion, the social history of witchcraft accusations should become more than a study of deviant behaviour. In dealing with witchcraft, researchers must explain not only why the alleged witch acted in a certain way, but also why the witch's neighbours and relatives suspected and accused him/her. It is possible that the alleged witch might have been responding to social or economic pressures when he/she cursed his/her enemies or used 'witchcraft' against them, but his/her neighbours and relatives, by denouncing him/her may be deemed equally responsive for having contributed to the social conditions in which they are living. It is equally true that witchcraft accusations in the Limpopo Province (as in early modern European communities) allow people to resolve conflicts between themselves and their neighbours and to explain misfortune that has occurred in their lives.

In establishing the social context in which witchcraft accusations are operating and the extent to which some of them may be attributed to failed interpersonal relationships, I will consider seven case studies from the Limpopo Province. These case studies are all based on kinship stresses, political tensions and unsettled communities.

This article addresses witchcraft accusations by employing the case study method. Two cases are thoroughly discussed in the paper using an oral history method. This is done to clarify why witchcraft accusations occur in some areas and not in others, and to apply the theoretical frameworks of oral history. By going directly to the social phenomenon of witchcraft accusations and observing it as fully as possible, one can develop a profound understanding of social factors that give rise to the problem. This mode of research is best done with a number of research topics that may assist researchers to recognise several nuances of attitudes and behaviour that might escape researchers using other methods (Babbie 1989: 262). In this respect, we will consider Lofland's insight on social research. 
In his Analysing social settings (1984: 71-92), Lofland identifies several appropriate kinds of foci for the case study method. He calls them thinking units. He lists them as follows:

1. Meanings - This includes linguistic devices such as culture, norms and world views.

2. Practices - This refers to various kinds of behaviour.

3. Episodes - This includes a variety of events such as crime and illness.

4. Encounters - This involves human relationships and interaction.

5. Roles - This refers to people's positions and their roles in family and society.

6. Relationships - This refers to the kinds of behaviour appropriate to pairs or sets of roles, such as mother-son relationships and friendships.

7. Groups - Moving beyond relationships, small groups such as friendship cliques, associations and professionals influence events in society.

8. Settlements - Smaller scale 'societies' such as villages, ghettos, neighbourhoods and methods used to sustain the society are also important for defining to society how to attend to its problems.

In the light of Lofland's thinking units, the following topic list has been formulated to provide direction and facilitate an understanding of witchcraft cases discussed in this study:

1. The village - Layout and composition of the village, provenance of families, administration of the village, business, schooling, main livelihood of the village, and links with the 'outside world'.

2. Agricultural infrastructures - How much land is cultivated, problems and shortages in agriculture, natural resources, cattle, natural hazards, employment opportunities, and individual roles in the community.

3. Relations between families - Kin relations, irksome kinship, role of larger groupings, market, and commercialisation in the village.

4. Tensions in the village - History of marriages and marital problems, relations between in-laws, brothers, people who are marginalised, interfamily feuds, struggles for power, problems with authorities, and tensions between villages.

5. Beliefs about witchcraft - How supernatural happenings are explained, scapegoating, jealousy, strives, conflicts, protection against witchcraft, and divination.

6. Accusations of witchcraft - Who is likely to be accused? Men, women, old, young, powerless, powerful. Who takes the initiative? Ways of identifying a witch, divination, smelling, sniffing? How counterclaims can be established? Role of the young and old in accusations. 
7. The effects of accusations - Witchcraft confessions, ways of cleansing or exonerating witchcraft accusations, witchcraft confessions.

The following two areas or farms were identified for this case study research: Makgabeng (Early Dawn) and Mongalo (Udeny). They were not selected randomly or because they had more problems than others, but selected because, according to police records, they had incidents of witchcraft accusations in the recent past and are basically rural villages

\section{MAKGABENG (EARLY DAWN) FARM}

\section{The location, topography and climate of the farm}

The Makgabeng farm is situated in the Central Region of the newly demarcated Northern Province. The province is divided into seven regions. Makgabeng is about $100 \mathrm{~km}$ north-west of Pietersburg. The area straddles the Tropic of Capricorn $23^{0} 30$. The altitude varies between $900 \mathrm{~m}$ and $1200 \mathrm{~m}$ above sea level. The area is gently sloping towards the Blouberg Mountain in the north, while the drainage is mainly from east to west along small spruits (streams) that flow into the Magalakwena River, a tributary of the Limpopo River. The annual rainfall varies between $380 \mathrm{~mm}$ and $550 \mathrm{~mm}$, with most of the rain during the summer months (October-February). The area is characterised by fairly frequent mid-season droughts that cause much frustration to crop farmers. The maximum summer temperature varies with the altitude and is around $25^{\circ}-35^{\circ} \mathrm{C}$ in summer and $17^{\circ}-22^{\circ} \mathrm{C}$ in winter. The area is not demarcated according to modern farming practices where the residential areas, ploughing fields and grazing camps are fenced into camps.

\section{Ethnic group and historical background}

The residents of the area are Northern Sotho people, one of the four ethnic groups that inhabit the Northern Province. The main clan is the Ngoepe clan. The farm was bought from the old Transvaal Administration by people residing on it in the early 1950 s and is classified as a privately owned farm with government having little say on the farm (Independent Development Trust 1998). Everything done on the farm, including modern agricultural methods, must be planned with the consent of the owners.

\section{Land use}

According to the Agricultural Report by the Independent Development Trust (IDT) of December 1998, the farming system in the area has developed after a long process of trial and error in an endeavour to fulfil the compelling necessity of basic needs 
within the constraints of the prevailing socio-economic, socio-cultural and political milieu. There is no water or irrigation system to ensure commercial farming. People who practise the subsistence mode of farming solely depend on rain for producing anything. There is only one communal borehole with a mono-pump that supplies the whole community with water. The constant shortage of water exerts tremendous pressure on the community, forcing some to travel long distances to buy water from those with their own boreholes.

\section{Grazing}

As indicated, Makgabeng is a privately owned farm. Because of the previous government's policy, resources were channelled to Trust farms (governmentcontrolled farms) while bought private farms were neglected. There are, therefore, no camps according to which the farm is planned; there is also no rotational grazing system practice. In addition, there is no co-operation between members of the community to manage their farm according to modern techniques. The effect of this lack of co-operation and systematic approach to use their farm as a resource is overgrazing, destruction of natural vegetation and starvation. On the other hand, there is a perceived reluctance in the community to reduce their stock to match the carrying capacity of the farm. Many cattle die because of these conditions and this increases the stress and tension in the community.

According to Madima (4), the average carrying capacity of Makgabeng farm is 14 hectares per one Life Stock Unit ${ }^{3}$ (14ha/LSU). At present, there is one LSU per 8 hectares. On the basis of the carrying capacity of the farm, the farm is grossly overstocked. This has resulted not only in the deterioration of the natural grazing and vegetation, but also in considerable tension and strife among the cattle owners. Given the population numbers on the farm, each family should have only 4 LSUs but it is impossible for one family to depend entirely on 4 LSUs. Matters are further complicated by the notion that the people regard stock keeping not as a business venture but a status symbol, and for speculative reasons cattle and goats are thus not kept for economic farming where profit-making is a motive but for personal prestige and gratification or egotism.

\section{Vegetation and grazing}

The land area is mixed veld. The trees found in the area are Sclerocarya caffra and Terminalla sericea, while grasses include Eragrotis species, Aristida and Schmidtia bulbosa. The natural vegetation is drought resistant and the kinds normally found in hot, dry and gravelly areas. Shorter trees are chopped down for firewood and for erecting fences for the fields and homesteads. 


\section{Type of soil}

The soil is dominantly shallow to very shallow brown apedal, gravelly loamy sands and sandy loams overlying weathering granite and rock. From the soil survey report by Maheya (1), the soil in Makgabeng is rated as having a low agricultural potential because the whole area is made up of Namib soil with a low agricultural potential because of its limitations, such as severe erosion due to its large sand proportion. Although drought resistant crops such as maize, grain, sorghum, millet and cowpeas can be planted, the soil is in a bad condition because of mono crop rotation and the lack of fertilizes and organic material in the soil. Because of the lack of infrastructure development, no commercial farming can be practised. Subsistence farming is also at its lowest ebb.

\section{The population statistics}

According to the agricultural census of 1997, the farm Early Dawn has one hundred and one (101) family units with a total population of 699. The average de jure family size is seven (7). Eighty per cent of family members live at home. There are seventyfive (75) men, one hundred and two (102) females, two hundred and seventy-six (276) boys and two hundred and forty-six (246) girls (Annual Census 1997).

With the high mortality rate of males, social practices such as polygamous marriages and labour migration, which estrange some men who work far from home, women have become the de facto heads of families. According to the Independent Development Trust (3), thirty per cent (30\%) of families in Makgabeng are de jure headed by women, mainly widows and single women. The age distribution of heads of the family units is skewed towards the upper age groups - sixty years and higher. This indicates that only a few new family units are being created while many young adults are living with their parents in an extended family. The cause of this is mainly the increasing unemployment rate in the country. Most of the heads of families have never been at school and are therefore illiterate.

The community's lack of trust in government officials from the Agriculture, Education, Health, Law Enforcement and Justice departments undermines any programme aimed at social development. The proximity of government offices plays a role in undermining or enhancing confidence in the government, while the authority of chiefs and indunas is undermined because of their inability to improve the living conditions of their subjects. The nearest police station is about fifty (50) kilometres away, the nearest hospital is thirty-five (35) kilometres from the village, while the nearest magistrate's court is one hundred (100) kilometres away. The nearest railway line is also a hundred (100) kilometres away. Moreover, the roads are in a bad condition. There are one primary school, one secondary school and one church building. So, some religious denominations thus have to hold their Sunday services in community school classrooms. 


\section{Land ownership}

Individual title to the land is vested in the original purchasers of the land and their heirs. People are mostly living in rondavels or flat-roofed houses with two to five rooms. There is no electricity in the houses, so wood and paraffin are used for cooking and heating. The problem of malnutrition is acute, while the absence of hygienic pit latrines on the farm is responsible for some diseases in the area. In addition, there are no water storage facilities strategically placed for communal use by both humans and animals, so they have to rely on the communal mono-pump, which is also not a reliable source of water. It is often dysfunctional because of a lack of gasoline or breakage, which forces people to walk long distances to adjacent farms to fetch water where they have to pay R5.00 for a hundred litres, which some families cannot afford.

Most households have no external source of income. Almost fifty per cent of family units depend solely on an income from old age state pensions. If livestock unit and crop production are taken into consideration, it is assumed that the average income per family unit is R5 900 (IDT: 3). The income is far below the acceptable living wage of R14 400.00 per annum. The improvement of the living conditions of the people in the area is closely related to the religious constraints of the people. These include the improvement of the water supply, energy supply (electrification of the area), upgrading of roads, inputs for agricultural production, improved schools and training, improved communication networks, employment opportunities, a radical change from blaming any tragedy on witchcraft and supernatural interventions, as well as seeking scapegoats for human failure. Effective strategic intervention should be made to improve the infrastructure and human conditions before any programme to change the mind-set could be effected.

\section{Subsistence farming}

All families on Makgabeng farm are practising subsistence farmers, that is, farmers who produce only enough crops for the farmer and his/her family to live on, leaving no surplus that can be sold. Farmers at Makgabeng follow virtually no crop rotation while they also practise mono-cropping with no application of fertilizer to their fields. As a result of this poor farming practice, all soils have low phosphate and nitrogen and moderate potash (IDT: 9) levels. In order to reach an acceptable production level, the soils require intensive strengthening through the incorporation of organic matter.

The mode of farming practised at Makgabeng is dry land crop production. Dry land farming is farming where no irrigation is practised since farmers depend entirely on rain. With a below average rainfall of $380-550 \mathrm{~mm}$ per year and poor soil with depleted organic material, the crop yield is frustrating. According to Bembridge (cf. IDT: 14), the citizens of Makgabeng have to purchase almost eighty per cent of 
their maize requirements from outside. This means they only get twenty per cent of their maize requirements from their fields. The subsistence farming practice is thus not supplying in all their needs.

In the preceding section, I have argued that communally owned rangeland is difficult to manage for sustained production because the land is normally not properly planned, while there is virtually no co-operation between owners. Problems such as soil erosion (the taking away of fertile topsoil from the land), the increase of insect pests and diseases, the depletion of organic soil material, and overgrazing result in many stressful situations that cause tension among the people.

The scenario presented above explains one of the most important issues in the consideration of victims of witchcraft accusation. Why is the belief more pronounced among underdeveloped areas and among basic rural agricultural communities? What are the stresses that favour its growth? Why is a certain class of people accused more often than others? I will return to these questions later in this study.

Evans-Pritchard (1937: 61) concludes that the concept of witchcraft provides the Azande people of Sudan with a natural philosophy by which the relations between people and unfortunate events are explained. A ready and stereotyped means of reacting to such events is thus presented. Witchcraft beliefs, he asserts, embrace a system of values that regulates human conduct. To this end, witchcraft plays its part in every activity of the Azande people's life - in agricultural, fishing, and hunting pursuits; in the domestic life of homesteads; as well as in the communal life of people. It is an important theme in the mental life in which it forms the background to a vast panorama of magic; its influence is clearly stamped on law, morals, etiquette, and religion; while it is prominent even in technology and language. To summarise, there is no niche or corner of culture in which it does not feature (Evans-Pritchard 1937: 62).

Evans-Pritchard found that any happening that has a negative impact on community life is blamed on witchcraft. If, for example, blight seizes a crop, it is blamed on witchcraft; if the bush is vainly scoured for game, it is witchcraft; if a wife is sulky and unresponsive to her husband, it is witchcraft; if the weather is cold, it is witchcraft; if, in fact any failure or misfortune falls upon anyone at any time and disturbs any normal activity of an individual, it may be blamed on witchcraft (EvansPritchard 1937: 64). All misfortunes, according to Evan-Pritchard, are attributed to witchcraft unless there exists strong evidence to the contrary.

Witchcraft is not less anticipated than, say, adultery. It is intertwined with everyday happenings that form part of some African people's ordinary world. There is nothing remarkable about a witch - anyone may be one - hence the saying, 'Moloi ga a na mmala' (a witch has no colour). African people expect people to become ill, but there are certain illnesses that are ascribed to witchcraft.

It is thus obvious that the agricultural conditions discussed in this section serve as precipitating factors for witchcraft accusations. To combat the carnage, agricultural 
factors must be addressed as well. It is thus clear that education without corrective agricultural and economic developments will achieve nothing. People need resources to sustain life, the absence of which may have catastrophic effects.

\section{Makgabeng (Early Dawn) episode}

In order to ensure the anonymity of the participants and informants, and to protect them from further harassment, the anthropological notation system of twelve primary terms is used. Pseudonyms and first letters of the names and surnames are also used to reduce additional confusion that may be caused by the notation system. The names of the people are denoted by the first letter of the notation while their surnames are denoted by the second letter of the notation. Where the first names and surname refer to more than one person, only the first letter of the first name is used.

According to my informants, Makgabeng's social conflict was triggered by the death of a certain woman nicknamed Gauta (Gold). She was married to J of Ngoepe's family (the main clan of Makgabeng). The death of Gauta was preceded by the death of her daughter, NR, a week earlier, and which was preceded by that of her son a few years earlier. According to the informants, the events unfolded as follows:

Gauta's daughter NR got ill after giving birth to a baby girl. She was ill for six months. She was coughing and became extremely emaciated. She was taken to traditional healers for medication but did not get better. One evening her condition deteriorated and she died the same night. The following Saturday she was buried and a hair-shaving ceremony was held. At this ceremony diviners were called to come and determine the cause of her death. At this ceremony three diviners were present to determine the cause of the death of NR, Gauta's daughter as well. ${ }^{4}$

The following diviners were present at the ceremony. E (female), Gauta's HBW (sister-in-law), S (male), Gauta's HeB, and P (a distant relative). The bones were thrown to establish the cause of the death. E's bone fall was: 'Ke morupi, ke a rupa letswele la mma le a hlaba le nhlaba ka matutu' (literally: I am a sufferer, suffering because of my mother's breast; my mother's milk is piercing me to death). The conclusion arrived at the ceremony was: 'nonyane e iphahlile ka lephego' (literally: a bird has upset the baby daughter's eye by its own wing). All three agreed with E's interpretation that Gauta had been responsible for her daughter's death. P, a distant relative (diviner), further cautioned Gauta and $\mathrm{E}$ that $\mathrm{S}$ (diviner, elder brother to Gauta's husband and E's husband) was grumbling that his younger brothers and their wives did not accord him the respect he deserved as the elder brother. This implied that his dissatisfaction might lead them into serious trouble if they did not change their attitude. The warning was not taken seriously. The ceremony came to an end with the assumption that Gauta had been responsible for the death of her daughter and if the family was not satisfied, it was at liberty to send out spells to kill the person 
responsible. Gauta's husband was expected to take the lead in getting a diviner to send out spells to the responsible witch. ${ }^{5}$

After the ceremony, Gauta experienced some discomfort with her stomach: she was constipated. She consulted a local diviner, $\mathrm{M}$, for a laxative to help her bowels to empty, but Gauta's stomach did not respond to the medication and this was a matter of concern for diviner M. He was heard complaining to Gauta's family members that Gauta was not responding to the treatment. Gauta's condition deteriorated and she died seven days after the funeral of her daughter. To some of her extended family members, this indicated that the spells sent out after her daughter's death had struck back and the victim was found. The fall of the bones was being vindicated by the events. But to the 'grave-diggers', the deaths of Gauta and her daughter were ascribed to the village witches. The grave-diggers felt that witches were freely killing innocent people without being checked. They regarded it their responsibility to make the witches account and pay a penalty for what they were doing.

After Gauta's funeral, the grave-diggers converged at the induna's kraal and demanded that each family be ordered to produce a sum of ten Rand (R10.00). The money collected would be used to transport a delegation to and from the Lowveld where a renowned diviner was residing. The induna was the first to produce the R10.00, followed by his subjects, including the victims listed below. An undisclosed sum of money was collected and given to a delegation that was sent to the Lowveld to consult a diviner who used a mirror ${ }^{7}$ in his divination. It is alleged that the diviner gave the delegates a certain mixture to drink, which intoxicated them and thereafter they started seeing witches in the mirror. The delegation returned with a list of nine (9) supposed witches at Makgabeng, whose full profile is presented below. They are listed in chronological order and according to the seriousness of their crime in the list below:

\section{List A}
a) $\mathrm{LN}-$ a wife to $\mathrm{DN}$
b) $\mathrm{EN}$ - a wife to $\mathrm{AN}$
c) $\mathrm{MN}-\mathrm{a}$ third wife to Lepokisi
d) RM - a friend to L, a cousin to L's husband and working in Johannesburg
e) MS - a third wife to $S$ and aunt to L
f) $\mathrm{RM}-\mathrm{a}$ sister to $\mathrm{MS}$
g) $\mathrm{TN}-\mathrm{a}$ brother to $\mathrm{L}$
h) $\mathrm{NN}$ - a relative to Ngoepe's family
i) $\mathrm{WN}-$ a stepbrother to $\mathrm{S}$ (diviner)

\section{Profiles of the Victims}

a. LN was the wife of DN - the first son of Liphokisi Ngoepe (LN). KN had three co-wives all marked $\mathrm{MN}$ in the diagram. LN's first son, $\mathrm{DN}$, had been 
working in Johannesburg since 1952 and got married to L (first victim). L was a hard-working woman and a disciplinarian. During her husband's absence, she ploughed the fields, hoed them and harvested the crops. She sent all her children to school. The first son was a qualified policeman and the other three had obtained degrees. She could achieve all these because her husband, DN, was sending her money from Johannesburg and she would seize every opportunity to plough her fields. LN and DN built a flat-roofed three-bedroomed house. According to local standards, they were a rich couple because the majority of their neighbours could not afford a cement and corrugated iron house and send their children to university. LN did not associate and socialise with other people as she was always pre-occupied with the welfare of her family. She did not drink liquor and she had a successful married life. LNwas 64 years old.

b. $\mathrm{EN}^{8}$ was the wife to AN, the last son of LN's second wife. AN had three brothers, $\mathrm{S}, \mathrm{P}$ and J. S was the elder brother and earned his living by subsistence farming and divination. $\mathrm{P}$ had not married and was staying with his younger brother, A was the husband to EN. EN was a female diviner and it was her bones that sniffed out Gauta as being responsible for the death of her daughter. She came from a village called Ga-Ramalapa, some fifty kilometres $(50 \mathrm{~km})$ south of Early Dawn. She was forty-five years old. When she got married to AN, she did not have the art of divination. She had learnt the art from her in-laws and this caused friction between her and her brother-in-law, S; S, who was in the business of divination as well. Her husband, AN, was employed in Polokwane as a labourer. His income was meagre and could not supply all the needs of the family. EN was supplementing it through her divination, selling liquor and chickens. Her divination business was lucrative in terms of local standards. She got many clients. P, her HeB (her brother in law) (unmarried), was collecting muti for her from nearby bushes. EN was also a prophetess in the Apostolic African Church in the village. She performed many roles in the community and was an outspoken person.

c. MN was the third wife of LN who had emigrated to Ga-Ramalapa (EN's home village) to live with her son. She was living with her son who built a tile-roofed house. She seldom visited Makgabeng and was, according to custom, to be living with her husband, LN. It is not clear why she had left Makgabeng. She earned a state old-age pension.

d. RM was an emigrant kitchen worker employed in Johannesburg. She was a bosom friend of L (accused number one). She was unmarried and was doing well as a single parent. She was a cousin to L's husband.

e. MS was the third co-wife of WS and stayed three kilometres from the place where the incident took place. She was LN's aunt and had three daughters and 
two sons. Two of her daughters were married and the lobola paid for them was a herd of cattle. She earned a state old-age pension.

f. RA was MS's sister and LN's aunt. She was married to WM, who was an emigrant labourer in Ellisras (an industrial town $300 \mathrm{~km}$ west of Pietersburg on the border of South Africa and Botswana).

g. TM was a brother to LN. He was working as a labourer in Pietersburg. He commuted from Early Dawn to Pietersburg by bus on a daily base.

h. NN was married to $\mathrm{WN}-$ a nephew to Lephokisi (LN). She was a housewife.

i. WN was a close relative of most of the accused and accusers. He was an emigrant worker.

\section{Relationships}

The victims were closely related and their accusers were their close relatives as well. Accused Number One was related to all eight victims. She was born in Mojela's family and married to Ngoepe's family. Her brother's wife (HeBW), EN, was accused Number Two and her father's widow (FiW), MN, was Accused Number Three. Her bosom friend, RM, was Accused Number Four and a niece to Accused Numbers Five and Six. LN was a sister to TM, Accused Number Seven, and a sister-in-law to NN and WN, Accused Numbers Eight and Nine.

$\mathrm{S}$, who was the chief instigator, according to the victims, was closely related to all. S was a brother-in-law to Accused Numbers One and Two. MN, Accused Number Three, was his FW and RM (Accused Number Four) was his cousin. Accused Numbers Five and Six were S's aunts and TM his brother-in-law while NN was his sister-in-law. WN, Accused Number Nine, was his stepbrother.

\section{The aftermath of the parade}

All the accused reported that they were shocked and stunned by the witch identification parade. They were ordered not to speak in their defence but to leave the farm within seven days or be burnt to death. Some of them fled on foot, the same night, to the police station, forty-five kilometres away. When they arrived at the police station, after two days of walking, they found the police on strike so they could not get any help from them. They went to their relatives to hire a truck, which could go to Early Dawn farm and rescue what could be salvaged. When they eventually returned to Early Dawn farm after four days, their properties had been burnt down. They could only rescue a couple of corrugated iron plates, which they used to erect tin-houses at their new place of abode. At first, some of the husbands were reluctant to join them on the journey to seek refuge. After a few consultations, the husbands joined them 
at the Matlala police station where they took refuge for six months. They were later settled on the farm Helena, twenty kilometres from the Matlala police station.

When Accused Number One (LN's son), who was a policeman working east of Pietersburg, heard what had befallen his parents he ran amok. He took his service revolver and went to the families of the ringleaders. He shot eight of them - four died on the spot and four were seriously wounded. At the end of the tragedy, he turned the gun on himself and killed himself. Five young lives were thus terminated because of the incident and nine families were displaced. A permanent rift was created between formerly close families and relatives. When the accusers were asked as to whether they could reconcile with their victims, they replied that reconciliation was not possible. Reconciliation could only take place if the victims could bring their dead ones back to life. The victims as well did not see any possibility of reconciling with their accusers. They all said the wounds caused could never be healed. They, therefore, decided to continue living in the squalor conditions in which they were.

\section{MONGALO (UDENY) EVENT}

\section{Background information}

Mongalo farm falls within the geographical boundaries of the greater Makgabeng and Mmalebogo. The farm occupies 1908 hectares and it lies $120 \mathrm{~km}$ west of Pietersburg. Mongalo farm is separated from Makgabeng farm by the Makgabeng Mountain Range, which is southwards towards the Magalakwena River. The farm has the same climatic conditions, soil type, vegetation, altitude and longitude as Makgabeng farm. People living on the farm are facing the same hardships as their neighbours. Like Makgabeng farm, Mongalo farm is a privately owned farm and is also underdeveloped.

The farm has a population of 789 with 120 family units. There are about 380 children and most of them do not make it beyond matric. On the farm there are two pre-schools, two primary schools and one high school, but no church building. There is also no clinic on the farm while the nearest hospital is $20 \mathrm{~km}$ away at the foot of Blouberg Mountain. There is only one road leading to and from the farm. The nearest bus stop is $5 \mathrm{~km}$ away on the main road from Pietersburg to Magalakwena River. People and domestic animals get their water from two communal boreholes.

Mongalo farm is ruled by three headmen: Mongalo, Nailana and Mampuru. There are some tensions between the headmen as there is competition to win the favour of the people on the farm. All three headmen are unemployed and earn their living through subsistence farming and getting state old-age pensions. They all resort under chief Malebogo who until the 1994 democratic election was very critical about apartheid rule in South Africa. It was partly because of this attitude that his area was neglected by the government. 


\section{Phoko ke phoko (Defamation has a decisive effect on its victims)}

The Mongalo episode, which had a ripple effect on the community, was triggered by the death of a school girl. After the death of the young girl, Malusi, a search for the allegedly responsible witches was launched, but a diviner had not been consulted after the death of Malusi although the victims were identified deductively. The bereaved families took all the events that had taken place before the death of their daughter into consideration and used them to find their witches.

List A represents the two families who were intermarried and between whom the conflict started. According to informants, the event unfolded as follows:

Malusi, a twelve year standard two girl, got ill around November 1993. Her condition gradually deteriorated until she could no longer attend school until her death in June 1994. Around March 1994 it was clear that she could no longer go to school that year. As she realised that she could not make it to school, Malusi sent a message, from her sickbed, to her cousin, JS, to bring her 1993 school report. ${ }^{9}$ JS fetched the report from the principal and handed it to Mika, Malusi's younger sister, to give to Malusi. According to the informants, Malusi was suffering from 'big or severe headache'. A few days after having received her report, Malusi died and was buried.

Another related incident that added to the intensification of the witch-hunt concerned that of a lost pen. In the second incident, JS had earlier lent her pen to her cousin and classmate, FK. FK lost the pen and reported to his cousin, JS, that the pen was lost. Initially it appeared as if the matter of the lost pen was settled. After the death of Malusi, her cousin, JS, got ill and her parents were concerned that she would die as well. They sent a message to FK's parents that JS was ill and if she would die they would be held responsible. ${ }^{10}$ The two incidents were, according to the affected families, proofs that PP and RS were targets of the witchcraft accusations. Tensions and anxieties escalated until the climax for a witch-hunt presented itself and daggers were drawn against the two families. List B portrays family relationships.

The son of MP enlisted the help of his comrades on the farm and started a witchcraft hunt. No diviner was involved to sniff out the village witches, but the two incidents had incited people to start the witch-hunt. Five victims (together with their parents) were identified and ordered to leave Mongalo. Before they could organise themselves to remove their belongings, their huts were destroyed. They fled to Bochum police station, some $25 \mathrm{~km}$ away. The following victims were evicted: PP, one of the co-wives of VP; MK, a first daughter to PP; and R1, a granddaughter to PP. RS, the second wife of MM; and her daughter-in-law, SS, were also evicted. The police came and helped carry their belongings to the Bochum police station where they were given temporary abode. No arrest was made and the victims were all relocated to a new residential area east of the police station. What remained was phooko (defamation of character). 


\section{The background of the families}

PP was a daughter of the Mojela clan who married WP of Phala's clan. MP was WP's first wife and eWB. WP's brother had passed away before MP bore a child and she was given to WP to ensure his brother's genealogy. Because MP was WP's elder brother by definition, he had to marry his own wife so he married PP as his rightful wife. MP gave birth to three boys. MP was his first son. WP's second wife, PP, gave birth to four girls and a son. MK was her first daughter who gave birth to FK.

The family had gone through many turbulent times during the fifty years prior to the incident. PP always conceived herself as the rightful wife of WP, but MP and her children reckoned that they were the senior 'house' and they should be accorded the necessary respect. MP, the elder son of WP, got mentally deranged when he was working in Johannesburg and had to stop working. PP was accused of bewitching him, but MP eventually recovered from his illness.

Another factor that made PP vulnerable was the fact that her first three children were girls and the boy came late in her life. She was always believed to be jealous of her co-wife's children because she had two sons. Boys are regarded as prosperity to the African family because the reproduction of the family is ensured and boys could also work in industries to provide for their children. Girls did not ensure any better prospects for their families because, when they grow up, they would marry and leave their families. Lobola paid for their marriages is not always regarded as a gain but merely a cancellation. In the case of their marriages breaking up, the lobola has to be refunded.

RS was a daughter of the Nonyane clan who got married to AS of the Seanego clan. AS had two co-wives and his first wife was MS, the sister of MM of Monyebodi. She had no children while MS had six children. As it became clear that RS would not bear any child after she had had three miscarriages, she married SS to bear children for her lineage. SS resultantly gave birth to JS who alleged that she was used to bewitch her cousin MM.

\section{Informants' circumstantial evidence that led to accusations}

According to some of the informants, they were singled out purely on the ground of jealousy and because they had not surrendered to the will and wishes of their co-wives and their children. PP, the second wife of WP, had four beasts, eighty-five sheep and six goats. This, according to an informant, evoked jealousy among her relatives who had none. She was receiving an old-age social pension as well while her co-wife's children were not receiving it because of their youth. PP, as surviving wife of WP who was also receiving an old-age pension, was seen by the children of MP as a thief as she was in effect getting a double pension, which she was not sharing with her co-wife's children. Instead, she was helping her daughter, MK, and her granddaughter RL (who were married and had their own families). MP's children 
always felt that PP had bewitched their mother in order to take their father as her husband for his wealth. The problem thus involved a crisis occasioned by suspicion, rumours, jealousy, the agony of poverty and religious beliefs.

RS, the co-wife of AS, was accused of having snatched her husband from MS. She was relatively young and skilled in the art of divination. She received an old-age pension as well. Her nickname was Nkokoto (a person with a strong will who cannot easily be conquered). SS, RS's daughter-in-law, was accused of witchcraft merely because she had allowed herself to be married by lapa (married to bear children to RS, according to tribal custom) and in that way had sided with the chief enemy of MS's family. It was thus concluded that she must have been a witch to have accepted such an arrangement. Because she was a witch, it was argued, she taught her daughter, JS, the art of witchcraft. In the scheme of things, it was contrived that she connived with her mother-in-law, RS, PP and all her daughters to bewitch MM for the enjoyment of it. An analysis of these circumstances will be given in the last part of this paper.

\section{WITCHCRAFT, GENERATIONAL INTERPERSONAL RELATIONSHIPS AND LEGITIMISATION OF INDIVIDUAL AND COLLECTIVE PERSECUTION}

In the last part of this article, I wish to draw on some theoretical approaches discussed in the two cases. In this regard, three statements will be considered: 1) witchcraft is something real in human experience; 2) witchcraft is an imaginary crime, 3) an explanation of witchcraft accusations seen through the lens of theories on society.

\section{Witchcraft is real in human experience}

In this study, I argued that witchcraft ideas are as widespread as humanity on the planet. I have, however, conceded there that there are basic communities in the world in which witchcraft beliefs do not occur. Mayer (1954: 4) found that among the Australian Aborigines and the Bushmen of South Africa the belief in witchcraft does not exist. This does not imply that these societies do not have interpersonal conflicts, but merely that they have their own ways of addressing them. The idea of magic is there but is never blamed on a person.

Among other communities, such as the Northern Sotho of the Limpopo Province, the witchcraft idea is real and it is clear, as seen from the cases discussed, that it must be related to something real in human experience. The objective of this study is thus to find out what the basic reality is that underlies witchcraft beliefs. By 'reality' I do not refer to a physical fact but a social and a psychological reality. My contention is that witchcraft beliefs and their resultant persecution are a response to social and 
psychological strains. The more exactly we identify those strains, the better we can understand and prescribe remedies to correct them.

From the cases discussed one thing is clear: people believe that the blame for some of their suffering rests upon a peculiar evil power, embodied in certain individuals in their midst (Mayer 1954: 4). The witch is thus held to be a person in whom a distinctive illness dwells, whereby he/she harms his/her own fellows in mysterious ways.

The following basic beliefs are held about witches:

- First, a certain category of persons, especially women, have recognisable and particular signs that single them out to be pointed out as witches. These people may bear physical stigma, like red eyes, have a reserved personality, be stingy, or quarrelsome (Mayer 1954: 5).

- Second, certain misfortunes are ascribed to witches. These include natural calamities such as death, illness, drought, or natural disaster (Stadler 1994: 88). However, the context of the misfortune is always apparent.

- Third, there is a belief that witches turn against their own people and kinsmen; they do not harm strangers or people from far away (Stadler 1994: 90).

- Fourth, witches they are spurred on by envy, malice or jealousy against individuals, rather than being in pursuit of material gain as such (Mayer 1954: $5)$.

- Fifth, witches reverse all normal standards. For instance, they eat their own children, dig up corpses, go naked in the night instead of being clothed, meet at particular spots to plan their evil deeds, and enjoy practising their art.

In addition, it is clear that different witchcraft incidents have different stimuli. Anxiety, tension, suspicion, rumours, as well as strains between kinsmen and neighbours seem to be among the chief contributories to the emergence of witchcraft accusations. Many events and situations create anxiety, tension and feelings of insecurity. Death, illness, natural disasters, or rapid change in society can create anxiety and stir emotions that may evoke persecution of some individuals in the society.

The routine response to death is a funeral, the routine response to sickness is medical treatment and the routine response to famine is the provision of food. The idea of witchcraft is employed on occasions when these routine responses alone do not provide an emotional solution (Mayer 1954: 5). Events thus create unusual anxiety and stress when they are viewed as unnatural or uncanny: they appear to counteract the ordinary course of events. Moreover, when events seem to be related to a supernatural power, they need supernatural explanations. These subjective factors may have profound implications if concerned with myth and religious beliefs. 
African cosmology clearly reveals that Africans ascribe the origin of evil to ancestors and witches. If an African thinks that his/her misfortune was sent by an ancestral spirit, he/she construes it as a moral sanction called upon by some misconduct of his/her own. But if an African thinks that misfortune comes from another human being, he/she would immediately jump to the conclusion that such a person has an evil heart. However, it is blasphemy to accuse the ancestors of any wrongdoing, but by blaming witches for the evil, Africans escape the need or temptation to blame the ancestors. Blaming witches for misfortunes exonerate Africans from being responsible for it and enhances a feeling of importance - they also draw the attention of the witches. If one has cultivated one's fields in the usual way, one may blame a witch for the failure of the crop, and so be saved from blaming oneself. If illness does not respond to treatment, one may blame a witch, and so be saved from doubting the worth of medical knowledge and practice. If the weather is extremely unfavourable, one may accuse the witches of being happy because it hurts other people.

Western Christians speak of natural disasters such as drought, tornadoes and floods as 'Acts of God', meaning that no human being can be blamed for them. In the same way, people blame witches for these disasters, thereby smoothing their dissonant feelings of guilt. By attributing witchcraft to someone else, one elevates oneself to a position of good because the witches are regarded as bad. Moreover, it is reasoned that because one is being bewitched, one is not a witch because witches do not bewitch one another. As such, witchcraft serves as a cosmological device, accounting for suffering that people may not be able to explain otherwise, and providing an alternative path for the sufferer to follow when he/she can no longer cope with the anxiety.

\section{Witchcraft is an imaginary crime}

In the African context, society creates the image of a witch, and pins it onto particular individuals. A witch is a social outcast, a person whose personality does not fit into the society. Witches are, therefore, always sought among people standing in a particular relationship. Although a witchcraft case may end in collective persecution by the whole community, it usually begins as a case between two antagonistic or mistrusted individuals. In this study, we have repeatedly pointed out that witches and their accusers are nearly always people who are close together. In typical cases the alleged witch is a neighbour and perhaps a kinsman of the accuser who has not been getting on well with him/her. Witches and their accusers are individuals who ought to like one another but do not. Painful tensions arise because one individual cannot feel towards the other as expected. By societal standards one ought to get on well with one's kinsman, neighbours, co-wives, and sisters-in-law. When failed relationships cannot be improved through reconciliation, rupture sets in. When a 
person thus complains that someone else is bewitching him/her, a warning is sounded that tensions and strains have reached a level where reconciliation is no longer possible. The witchcraft accusation, therefore, serves as a device that enables people to clothe their animosities in the guise of an offence committed against themselves (Mayer 1954: 13).

Witchcraft is a convenient device that can be used against one's enemy because of its effectiveness. Once a person names another person a witch, there is virtually no chance that the two persons may be reconciled. People who do not reconcile and smooth out their relations with their neighbours and kinsmen will follow this course. It is also true that witchcraft accusations reveal the nature of a relationship. It helps the accuser to avoid the laborious and time-consuming legal procedure of fighting his/her enemies. If well-planned, the victims stand very little chance of escape. Moreover, witchcraft accusations do not need legal proof, so the belief can be kept on a private level without fear of being proven wrong. As such, they can remain duels between two people.

In addition, public condemnation of those who are regarded as witches can serve the purpose of scapegoating while the public collective persecution of supposed witches has a cathartic function: it purges the community of certain anxieties. It lets people feel that they have found a public enemy who made things difficult for them, that they have identified and destroyed an enemy. They resultantly feel relieved because they have removed a 'thorn from their flesh'. But public persecution of supposed witches cannot satisfy everybody, hence individuals may still have their own witches on their minds.

We may conclude by remarking that a community ridden by witchcraft related feuds and duels is a sick society. Witchcraft phenomena are indicators of communities undergoing painful stress. In a normal society with all its needs and wants, witchcraft epidemics are effectively under control. For a society to function smoothly without conflicts manifesting themselves in witchcraft disputes, safety valves must be provided. Some of these control outlets are effective tools for the management of social change, for curbing poverty and population explosions while simultaneously providing a purpose-driven agenda or vision for the society, and aiding in effective inter-personal management.

In conclusion, while agreeing with Girard's analysis, we affirm that the myth of Oedipus is not just a literary text, but a mythical text based on the justification of collective persecutions such as those in witcheraft trials. Mythical texts are not historical and it is dangerous to treat them as if they were historical. On the contrary, genuine historical evidence plays no important role in deciphering representations of collective persecutions. The question of historical realism is normally asked when representations of witchcraft trials are evoked because the mythical crosscurrents and undercurrents inform the persecutors. The nature and disposition of the persecutors determine who must be singled out as a witch because of his/her stereotypes. Without 
this basis it is impossible to explain why and how the persecutors would refuse to listen to any legal and historical arguments that refute their claims.

An analysis of the interpretation that automatically results in the identification of stereotypes of persecution is necessary in order to understand the nature of witch persecutions. The following story told by one of the people accused of striking lightning in Mantheding Village in 1995 has relevance here:

Harvests were bad, the cows gave birth to dead calves; no one was on good terms with anyone else. Mohlapamaswi's beasts were doing well. He woke up early in the morning to cut grass on the farms of white farmers to feed his beast. He donated a wire fence to a local school. All fortunes appeared to be on his side because his beasts, children and fields were doing well. A woman (a widow) carrying firewood from her field was struck by lightning. All sorts of things were said about Mohlapamaswi. How did he succeed? He should be using human flesh as muti to flourish, he is responsible for the lightning that has struck the woman. One day the fellows - under the leadership of Mohlapamaswi's brothers from Gauteng - took it to a diviner. The diviner was told who the victim was before he could divine. Mohlapamaswi was picked out as the victim. The diviner told the police how Mohlapamaswi was picked out (Informant Raphesu).

An unbiased reader would understand that the victim did not do what he was accused of but that everything about him marked him as an outlet for the annoyance and irritation of his fellow brothers and citizens. No one will suggest that it is an innocent incident, no one will see it as a figment of the imagination. But we can sense a form of cultural schizophrenia in the story. Here, the persecutors were trapped by an external influence prompted by jealousy conveyed in myth. Myth can be involved in a social crisis as presenting a lack of differentiation. Myth usually encourages a catastrophe juxtaposing what has occurred during a social upheaval and a similar mythical story.

All crimes that witch-persecutors attribute to their victims can generally be found in myth. In pre-literary communities, these myths corresponded perfectly to the societal stereotypes. In the myths there appear formidable chief characters who are criminals and who are treated as such. Because of this they incur a punishment that is usually attributable to victims of collective persecutors in real life. In the majority of these myths, stereotypes have marks that identify them for selection as victims for collective persecution. The whole range of victim signs can be found in myth, a fact often missed because of the focus on the victim's ethnic or religious minority and even the absence or presence of differences.

In groups people are subject to sudden variations in their relationships, for better or worse. If they attribute a variation to the collective victim who can, in turn, facilitate the return to normal, they will deduce from their belief a transcendental power that will bring them alternatively both loss and health, punishment and recompense (Girard 1986: 44). This belief is manifested through the acts of violence instigated by the victim as the mysterious instigator. The causality of the scapegoat 
is imposed on the victim with such force that even death cannot prevent it. Where group relationships have deteriorated and that is blamed on a victim, the group will commemorate the social ills in conformity with the illusory mythical belief that the scapegoat is omnipotent and has facilitated the cure.

\section{Belief in witchcraft serves a particular purpose in societies}

From the case studies discussed in this article, it became clear that witch-hunters justify their actions by posing to be working in the interest of the whole community. They see themselves as working for the protection and preservation of cultural norms, morality and values. They regard themselves as custodians of what is good for the community while they see their actions as ensuring the orderly continuance of the society by punishing those who are intent on destroying the fabric of the society through their ill-conceived craft. Both 'grave-diggers' and youth 'gangs' mobilise communities against individuals perceived to be outcasts and malicious characters who are free to cause havoc in the community by destroying lives.

The underlying notion here is that all parts of the society are interrelated, and all must contribute to the smooth functioning of the whole community. This is even evident in their demand, in the case where a diviner must be consulted, when the members of the community are compelled to fork out money for consultation with a diviner. The witchcraft incidence, although concerning one individual at the start, is later taken over by the mob as its societal responsibility.

My contention is that social structures should be treated and studied as part of the total sum in witchcraft discourse. Even social factors that can be treated as external to individuals do exert control over them. Individual behaviour is, to a large extent, governed by social pressures. Sometime a dissident is named, isolated, sanctioned, or persecuted under a wrong charge. This form of social control minimises individual freedom and autonomy. Victims are those who stand up and claim their rights. Thus witchcraft accusations serve as sanctions and control of individual conduct and autonomy. They are a form of slavery.

At the end of each interview, each victim was asked whether he/she still believed that witchcraft existed. Some replied in the affirmative while some expressed doubt. Those who expressed doubt substantiated their position by adding that if people accused of witchcraft were like them then witchcraft does not exist. Those who replied in the affirmative said that they believed in the existence of witchcraft because they were born into a society that believed in witchcraft. They could not negate the society's belief, but they, including all male and female diviners, had never seen a single witch in their lifetime. They did not find anything wrong with their belief in witchcraft despite the fact they had never seen one. But they all conceded that many people are accused of witchcraft solely out of jealousy, hatred and tensions in the 
society. From this observation, witchcraft remains an unproven crime supported by societal belief.

In this study one of the most fruitful observations is the investigation of the relationships of the people who were accused of bewitching one another. Two main categories must be distinguished. That is, cases in which relatives bewitch one another and cases in which non-relatives are involved. In all the cases discussed only one case, that of Avon farm, involves non-relatives. It could be explained, as it has been done, why non-relatives were involved. But the rest involved kin living in extended networks of families. The Northern Sotho people maintain that witches mainly injure those with whom they are in close contact, that is, relatives and neighbours, and that it is difficult to bewitch a stranger.

The most prolific single source of witchcraft is conflict among co-wives, brothers and sisters, living in extended families, lovers competing to win the love of a man, neighbours envying their competitors and relatives failing to manage impressions they have been creating to one another. These factors explain why a community staggering under the scarcity of resources is more prone to witchcraft accusations, more than those in urban areas where people lead more individualistic and busy lives. In other words, witchcraft is a reflection of tensions within the framework of cultural mechanisms for control and the creation of a 'utopian egalitarian' society free of evil and tension. The causes of witchcraft accusations should, therefore, be sought in the whole configuration of institutions and social values: the permissible or approved conduct, the interposition of the hierarchy of clan, age and rank between competing individuals, the compromises and reconciliations that are insisted upon, and the extent to which mental and physical anguish for personal liberty is allowed and curtailed. Cultural patterns and values, as well as stress put on individuals within the social systems, must be carefully studied and modified where necessary to allow human freedom within society.

White anthropologists have concluded that witchcraft is a reflection of the intense hatred that the black person's mind is capable of (Krige 1943: 169). It is true that Blacks attribute many crimes to witchcraft for the most trivial reasons. But Europeans have committed crimes that have left Blacks appalled at the evil European minds are capable of. What is true is that humankind is capable of conceiving and thinking of unimaginable evil given the conditions and space to do so. Moreover, the evil that humanity can produce is historically conditioned. Scarce natural resources, cultural limitations and frustrations caused by living conditions and misfortunes that may befall a person may drive him/her to extreme limits. Illness, suffering and death may compel people to seek the cause in the direction of jealousy, hatred and scapegoating, which are encapsulated in witchcraft accusations and are used to provide emotional satisfaction to the bereaved (Kriger 1943: 270). Witchcraft also serves to explain the differential incidence of misfortune or death that cannot otherwise be explained to the bereaved family or community. 


\section{NOTES}

1. Limpopo Province is one of nine provinces in South Africa. It is situated in the north of the country bordering with Zimbabwe in the north.

2. Prof S T Kgatla is Extraordinary Professor in Theology and Religious Studies at UNISA.

3. Life Stock Unit is equivalent to one beast of five goats/sheep.

4. A hair-shaving ceremony is held immediately after the funeral where the heads of relatives are shaved. It partly determines the length of the mourning periods because after a certain period, when the hair will have grown to a particular length, the mourning will be ended by another hair-shaving ceremony. The death of NR was preceded by the death of her brother, Nare, who had also died mysteriously.

5. All the accused in the case believe that J Gauta's husband consulted with diviners and sent the spells that later killed Gauta, his wife.

6. In rural areas graves for their dead are dug by 'grave-diggers' normally known as diphiri (wolves). They are called wolves because they are working with the soil as wolves are also involved with the soil as they get their food from left-overs from lions. Lions' leftovers are wrapped in soil and are not regarded as decent food.

7. Generally diviners use bones to sniff out witches or to diagnose illness. Some use water in a clay dish, which serves as a mirror. It is believed that after taking a certain drink the complainant would start seeing his/her witches in the mirror or water.

8. E was a competitor of Gauta and was being initiated to become a diviner. E's husband was a blood brother to Gauta's husband.

9. Malusi could not get her 1993 school report when the school closed because she had lost a school textbook lent to her. She found the book around February 1994 and it was then that she could send her cousin to the principal with the book in order to release her school report. Malusi and her cousin JS were in the same standard.

10. Severe headache is normally associated with hypertension and is usually not ascribed to witchcraft. But when it leads to death it is viewed as something else. Death, especially the death of a young person, stirs emotions and may have serious consequences.

\section{REFERENCES}

Babbie, E. 1989. The practice of social research. Belmont: Wadsworth Publishing Co.

Baholo, K.R. 1994. A pictorial response to certain witchcraft beliefs within Northern Sotho communities. MFA, University of Cape Town, Cape Town, South Africa.

Evans-Pritchard, E.E. 1937. Witchcraft, oracles and magic among the Azande. Oxford: Clarendon Press.

Girard, R 1982. The scapegoat. Baltimore: Johns Hopkins University Press.

Kgatla, S. T. 2000. Moloi ga na mmala (A witch has no colour). Unpublished PhD thesis submitted to the Department of Religious Studies at UNISA, Pretoria. 
Kriger, J.D. 1943. The realm of a rain-queen. A study of the pattern of Lovedu society. Johannesburg: Juta \& Co.

Levack, B. 1987. The witch-hunt in early modern Europe. London: Longman.

Lofland, J. 1984. Analysing social settings. Belmont: Wadsworth.

Maheya. n.d. Unpublished report on Early Dawn farm to the Department of Agriculture. Pietersburg.

Mayer, P. 1954. Witches. Grahamstown: Rhodes University.

Stadler, J. 1994. Witches and witch-hunters. Witchcraft, generational relations and the life cycle in a Lowveld village. African Studies 55(1): 88-110. 